\title{
High-Throughput Sequencing Indicates Novel Varicosavirus, Emaravirus, and Deltapartitivirus Infections in Vitis coignetiae
}

\author{
Tomoyuki Nabeshima ${ }^{1, *,+}$ (D) and Junya Abe ${ }^{2,+}$ \\ 1 Department of Agriculture, Yamagata University, Tsuruoka 997-8555, Japan \\ 2 Smart Agriculture Division, JFE Engineering Corporation, Yokohama 230-8611, Japan; abe-junya@jfe-eng.co.jp \\ * Correspondence: nabeshima@tds1.tr.yamagata-u.ac.jp; Tel.: +81-235-28-2906 \\ + These authors contributed equally to this work.
}

check for

updates

Citation: Nabeshima, T.; Abe, J. High-Throughput Sequencing Indicates Novel Varicosavirus, Emaravirus, and Deltapartitivirus Infections in Vitis coignetiae. Viruses 2021, 13, 827. https://doi.org/ $10.3390 / v 13050827$

Academic Editor: K. Andrew White

Received: 13 April 2021

Accepted: 2 May 2021

Published: 3 May 2021

Publisher's Note: MDPI stays neutral with regard to jurisdictional claims in published maps and institutional affiliations.

Copyright: (c) 2021 by the authors. Licensee MDPI, Basel, Switzerland. This article is an open access article distributed under the terms and conditions of the Creative Commons Attribution (CC BY) license (https:/ / creativecommons.org/licenses/by/ $4.0 /)$.
Abstract: Vitis coignetiae samples were collected from several locations in the northern area of Japan, and virome analysis using a high-throughput sequencing technique was performed. The data indicated that some of the collected samples were in mixed infections by various RNA viruses. Among these viruses, three were identified as newly recognized species with support of sequence identity and phylogenetic analysis. The viruses have been provisionally named the Vitis varicosavirus, Vitis emaravirus, and Vitis crypticvirus, and were assigned to the genus Varicosavirus, Emaravirus, and Deltapartitivirus, respectively.

Keywords: next-generation sequencing (NGS); virome; RNA virus; grape

\section{Introduction}

Recent developments in high-throughput sequencing (HTS, or Next-Generation Sequencing (NGS)) technologies and bioinformatic analyses have resulted in advances in detecting viruses in plants [1,2]. Using HTS technologies, increasing numbers of studies describe novel viral species or strains, complex virome status in planta, or geographical distribution of viruses. These studies contribute to the understanding of viral ecology and evolution, pathogenicity, hosts, and epidemiology [1,2]. Additionally, these technologies are progressively reaching practical fields, such as diagnostic [3] or quarantine regulations [4].

The genus Vitis comprises more than 60 species. The most well-known and economically important Vitis species is the Vitis vinifera subsp. vinifera, which is the western Eurasian species. Vinifera's ancestor is the wild Vitis vinifera subsp. sylvestris, naturally occurring in Europe, the Middle East, and Northern Africa [5]. Because cultivated grapes are perennial crops, and their propagation is mainly dependent on vegetative propagation, viral diseases pose considerable problems. Many researchers have been focusing on viral diseases in grapes, and more than 80 species of viruses have been described [6]. However, reports on viral infection in wild Vitis are elusive. Similarly, up to 30 grapevine species are native to East Asia and North America. Among these, the crimson glory vine (V. coignetiae) is native to the East Asian Pacific Refuge [5]. They naturally grow in areas of cool temperature and are distributed in Russia, Southern Kurile Islands, and Japanese Islands. In Japan, wild $V$. coignetiae is commonly found throughout the Japanese Islands, and they are also cultivated for fresh fruit, jams, juices, dried fruits, and production of wine [7]. In Korea, they are also used as a Korean folk medicine to treat various diseases, such as cancer and inflammatory disorders [8].

In this study, we performed an HTS analysis using $V$. coignetiae samples collected in Japan. The sequence data were then used to analyze viral sequences, from which we identified three novel RNA viruses. 


\section{Materials and Methods}

\subsection{Plant Materials and RNA Extraction}

In September 2020, wild Vitis coignetiae leaf samples from several locations in the northern area of Japan (Table 1) were collected. Samples were stored at $-80{ }^{\circ} \mathrm{C}$ until extraction. Frozen samples were also homogenized using a freeze crusher $\mu \mathrm{T}-48$ (Taitec, Koshigaya, Japan) with supplied stainless beads. Total RNA was extracted using ISOSPIN Plant RNA with an assist buffer (Nippongene, Tokyo, Japan) and according to the manufacturer's instructions.

Table 1. Summary of Vitis coignetiae sample information used in this study.

\begin{tabular}{|c|c|c|c|c|c|c|c|c|}
\hline \multirow{2}{*}{ Pool } & \multirow{2}{*}{ Sample No. } & \multirow{2}{*}{ Location (Prefecture) } & \multirow{2}{*}{ Symptom } & \multicolumn{5}{|c|}{ Viral Infection a } \\
\hline & & & & VVV & VEV & VCV & GPGV & GINV \\
\hline \multirow{15}{*}{ A } & 1 & $45^{\circ} 07^{\prime} 46.59^{\prime \prime} \mathrm{N}, 142^{\circ} 12^{\prime} 06.04^{\prime \prime} \mathrm{E}$ (Hokkaido) & Mosaic & + & - & - & + & + \\
\hline & 2 & $45^{\circ} 07^{\prime} 44.85^{\prime \prime} \mathrm{N}, 142^{\circ} 12^{\prime} 05.18^{\prime \prime} \mathrm{E}$ (Hokkaido) & None & - & - & + & + & + \\
\hline & 4 & $45^{\circ} 07^{\prime} 42.63^{\prime \prime} \mathrm{N}, 142^{\circ} 12^{\prime} 02.99^{\prime \prime} \mathrm{E}$ (Hokkaido) & None & - & + & + & - & - \\
\hline & 5 & $45^{\circ} 07^{\prime} 41.91^{\prime \prime} \mathrm{N}, 142^{\circ} 12^{\prime} 02.86^{\prime \prime} \mathrm{E}$ (Hokkaido) & None & - & + & + & - & - \\
\hline & 6 & $45^{\circ} 07^{\prime} 40.39^{\prime \prime} \mathrm{N}, 142^{\circ} 12^{\prime} 02.21^{\prime \prime} \mathrm{E}$ (Hokkaido) & None & - & + & + & - & - \\
\hline & 7 & $45^{\circ} 07^{\prime} 43.23^{\prime \prime} \mathrm{N}, 142^{\circ} 12^{\prime} 03.69^{\prime \prime} \mathrm{E}$ (Hokkaido) & Mosaic & - & - & - & + & + \\
\hline & 8 & $45^{\circ} 07^{\prime} 46.74^{\prime \prime} \mathrm{N}, 142^{\circ} 12^{\prime} 03.09^{\prime \prime} \mathrm{E}$ (Hokkaido) & Mosaic & + & - & - & + & + \\
\hline & 9 & $45^{\circ} 07^{\prime} 49.68^{\prime \prime} \mathrm{N}, 142^{\circ} 11^{\prime} 24.80^{\prime \prime} \mathrm{E}$ (Hokkaido) & None & - & - & + & + & + \\
\hline & 11 & $44^{\circ} 57^{\prime} 27.96^{\prime \prime} \mathrm{N}, 142^{\circ} 13^{\prime} 19.85^{\prime \prime} \mathrm{E}$ (Hokkaido) & None & - & - & + & - & - \\
\hline & 12 & $44^{\circ} 52^{\prime} 55.93^{\prime \prime} \mathrm{N}, 142^{\circ} 12^{\prime} 43.34^{\prime \prime} \mathrm{E}$ (Hokkaido) & None & - & - & - & - & - \\
\hline & 13 & $44^{\circ} 56^{\prime} 25.57^{\prime \prime} \mathrm{N}, 142^{\circ} 13^{\prime} 28.72^{\prime \prime} \mathrm{E}$ (Hokkaido) & None & - & - & - & - & - \\
\hline & 14 & $44^{\circ} 56^{\prime} 15.11^{\prime \prime} \mathrm{N}, 142^{\circ} 13^{\prime} 18.44^{\prime \prime} \mathrm{E}$ (Hokkaido) & None & - & - & - & - & - \\
\hline & 15 & $44^{\circ} 53^{\prime} 35.22^{\prime \prime} \mathrm{N}, 142^{\circ} 12^{\prime} 10.86^{\prime \prime} \mathrm{E}$ (Hokkaido) & None & - & - & - & - & - \\
\hline & 16 & $44^{\circ} 53^{\prime} 33.27^{\prime \prime} \mathrm{N}, 142^{\circ} 12^{\prime} 06.99^{\prime \prime}$ E (Hokkaido) & None & - & - & - & - & - \\
\hline & 17 & $44^{\circ} 53^{\prime} 30.92^{\prime \prime} \mathrm{N}, 142^{\circ} 12^{\prime} 07.58^{\prime \prime} \mathrm{E}$ (Hokkaido) & None & - & + & + & - & - \\
\hline \multirow{18}{*}{ B } & 18 & $43^{\circ} 08^{\prime} 03.04^{\prime \prime} \mathrm{N}, 140^{\circ} 49^{\prime} 27.85^{\prime \prime}$ E (Hokkaido) & None & - & - & + & - & - \\
\hline & 19 & $43^{\circ} 08^{\prime} 00.95^{\prime \prime} \mathrm{N}, 140^{\circ} 49^{\prime} 30.55^{\prime \prime} \mathrm{E}$ (Hokkaido) & None & - & + & + & - & - \\
\hline & 20 & $43^{\circ} 00^{\prime} 28.97^{\prime \prime} \mathrm{N}, 140^{\circ} 52^{\prime} 34.70^{\prime \prime} \mathrm{E}$ (Hokkaido) & None & - & - & - & - & - \\
\hline & 21 & $43^{\circ} 00^{\prime} 23.97^{\prime \prime} \mathrm{N}, 140^{\circ} 52^{\prime} 41.01^{\prime \prime} \mathrm{E}$ (Hokkaido) & None & - & - & - & - & - \\
\hline & 22 & $43^{\circ} 21^{\prime} 23.14^{\prime \prime} \mathrm{N}, 142^{\circ} 14^{\prime} 37.98^{\prime \prime}$ E (Hokkaido) & None & - & - & - & - & - \\
\hline & 23 & $43^{\circ} 21^{\prime} 18.17^{\prime \prime} \mathrm{N}, 142^{\circ} 14^{\prime} 35.64^{\prime \prime} \mathrm{E}$ (Hokkaido) & None & - & - & + & - & - \\
\hline & 24 & $43^{\circ} 27^{\prime} 19.82^{\prime \prime} \mathrm{N}, 142^{\circ} 30^{\prime} 06.96^{\prime \prime} \mathrm{E}$ (Hokkaido) & None & - & - & + & - & - \\
\hline & 25 & $43^{\circ} 27^{\prime} 19.88^{\prime \prime} \mathrm{N}, 142^{\circ} 30^{\prime} 14.23^{\prime \prime} \mathrm{E}$ (Hokkaido) & None & - & - & - & - & - \\
\hline & 26 & $43^{\circ} 26^{\prime} 21.10^{\prime \prime} \mathrm{N}, 142^{\circ} 35^{\prime} 43.27^{\prime \prime} \mathrm{E}$ (Hokkaido) & None & - & + & + & - & - \\
\hline & 30 & $40^{\circ} 11^{\prime} 22.55^{\prime \prime} \mathrm{N}, 141^{\circ} 29^{\prime} 15.77^{\prime \prime} \mathrm{E}$ (Iwate) & Leaf roll & - & - & + & - & + \\
\hline & 31 & $40^{\circ} 07^{\prime} 45.35^{\prime \prime} \mathrm{N}, 141^{\circ} 31^{\prime} 08.13^{\prime \prime} \mathrm{E}$ (Iwate) & Leaf roll & - & - & + & - & + \\
\hline & 32 & $40^{\circ} 07^{\prime} 44.72^{\prime \prime} \mathrm{N}, 141^{\circ} 31^{\prime} 04.26^{\prime \prime} \mathrm{E}$ (Iwate) & Leaf roll & - & - & + & - & - \\
\hline & 33 & $40^{\circ} 07^{\prime} 45.17^{\prime \prime} \mathrm{N}, 141^{\circ} 30^{\prime} 59.01^{\prime \prime} \mathrm{E}$ (Iwate) & Mosaic & - & - & + & - & + \\
\hline & 34 & $39^{\circ} 00^{\prime} 18.48^{\prime \prime} \mathrm{N}, 140^{\circ} 51^{\prime} 42.33^{\prime \prime} \mathrm{E}$ (Iwate) & None & - & - & + & - & - \\
\hline & 35 & $39^{\circ} 00^{\prime} 15.42^{\prime \prime} \mathrm{N}, 140^{\circ} 51^{\prime} 35.98^{\prime \prime} \mathrm{E}$ (Iwate) & None & - & - & + & - & - \\
\hline & 36 & $39^{\circ} 59^{\prime} 03.19^{\prime \prime} \mathrm{N}, 140^{\circ} 43^{\prime} 08.54^{\prime \prime} \mathrm{E}$ (Akita) & None & - & - & - & - & - \\
\hline & 37 & $38^{\circ} 58^{\prime} 51.20^{\prime \prime} \mathrm{N}, 140^{\circ} 43^{\prime} 04.73^{\prime \prime} \mathrm{E}$ (Akita) & None & - & - & + & - & - \\
\hline & 38 & $39^{\circ} 00^{\prime} 55.83^{\prime \prime} \mathrm{N}, 140^{\circ} 38^{\prime} 36.00^{\prime \prime} \mathrm{E}$ (Akita) & None & - & - & + & - & - \\
\hline
\end{tabular}

a Viral infection was determined by RT-PCR. VVV: Vitis varicosavirus, VEV: Vitis emaravirus, VCV: Vitis cryptic virus, GPGV: grapevine Pinot gris virus, GINV: grapevine berry inner necrotic virus. +/ - indicates positive/negative virus.

\subsection{HTS}

RNA samples were bulked into two groups: 15 leaf samples (including three symptomatic leaves) from Hokkaido (hereafter called pool A for convenience) and the other 19 samples from Hokkaido and the North-East area of mainland Japan (pool B). Sequentially, bulked RNA was subjected to the construction of a cDNA library using the MGIEasy RNA Directional Library Prep Set (MGI Tech Co Ltd., Shenzhen, China). The DNA nanoballs (DNBs) were then prepared using the DNBSEQ-G 400 RS HTS Kit (MGI Tech Co., Ltd.), after which the generated DNBs were sequenced using DNBSEQ-G400 ((MGI Tech Co Ltd.) under $2 \times 100$ bp conditions. We obtained 38,507,344 and 35,823,926 reads from the pools $\mathrm{A}$ and $\mathrm{B}$, respectively. Trimming of reads by their quality and de novo assembly was also performed using the CLC Genomic Workbench software (ver. 8.5.1; Qiagen, Hilden, North Rhine-Westphalia, Germany). Contigs shorter than 500 nt were discarded. To extract exogenous sequences, trimmed reads were mapped onto the $V$. vinifera genome $(12 \times$, GenBank 
assembly accession: GCA_000003745.2); then, unmapped sequences were collected before the de novo assembly. The aforementioned procedure resulted in 2260 and 1444 contigs from pools A and pool B, respectively, which were then used for subsequent analysis.

\subsection{Analysis and Comparison of Viral Genome and Encoded Proteins}

BlastN, BlastX, and BlastP analyses were performed at the National Center for Biotechnology Information (NCBI) against the database set for "viruses" (taxid: 10239). All the obtained contigs ( $>500 \mathrm{nt})$ were then subjected to BlastN and BlastX analyses. Annotations of subjects up to 100 were checked seeking for viral proteins (genome sequences) one by one, after which candidate contigs were selected for further studies. The ORF finder at NCBI was also used to find open reading frames (ORFs) in the candidate viral genomes. A minimal ORF length of $300 \mathrm{nt}$ was considered. Protein motifs were also identified using the MOTIF finder at the Kyoto University Bioinformatics Center (https: //www.genome.jp/tools/motif/, accessed on 6 April 2021) against the Pfam database. Alignment and phylogenetic analyses of the expected amino-acid sequences of viral proteins were also performed using MEGAX software (v10.2.2) [9]. Multiple sequence comparison by Log-Expectation was used for the alignment of amino-acid sequences, whereas the protein alignment tool was implemented using the CLC Genomic Workbench software to create visual images of the amino-acid sequence alignments and identical positions. For constructing a phylogenetic tree, the maximum likelihood method based on the JTT matrix-based model [10] with 1000 bootstrap replications was conducted. The percentage of nucleotide and amino-acid sequence identity was analyzed using a needle in EMBOSS (https://www.ebi.ac.uk/Tools/psa/emboss_needle/, accessed on 6 April 2021) between identified viruses and related viruses. In silico, protein analyses were also performed using the following software: NetNGlyc 1.0 server, http:/ / www.cbs.dtu.dk/services/NetNGlyc/ (accessed on 6 April 2021) for predicting glycosylation sites; TMHMM server v. 2.0, http:/ /www.cbs.dtu.dk/services/TMHMM/ (accessed on 6 April 2021), transmembrane helices; and SignalP 4.1 server, http:/ / www.cbs.dtu.dk/services/SignalP-4.1/ (accessed on 6 April 2021), signal peptides.

\subsection{RT-PCR}

Reverse transcription (RT) was conducted in a $10-\mu \mathrm{L}$-volume containing 50 units of ReverTra Ace (Toyobo, Osaka, Japan), $1.0 \mu \mathrm{L}$ RT buffer, $1 \mathrm{mM}$ dNTPs (10 mM), 20 U RNase inhibitor (Toyobo), and $1.0 \mu \mathrm{M} 6$ mer random primer (Random Primer (hexadeoxyribonucleotide mixture; pd (N)6); TakaRa, Kusatsu, Japan). Total RNA was added to the reaction mixture to arrive at a final concentration of 10 to $20 \mathrm{ng} \cdot \mu \mathrm{L}^{-1}$, after which the mixture was incubated at $42{ }^{\circ} \mathrm{C}$ for $30 \mathrm{~min}$ and $99{ }^{\circ} \mathrm{C}$ for $5 \mathrm{~min}$. The RT product was then added to a $9.0 \mu \mathrm{L}$ of the PCR mixture to obtain a final volume of $10 \mu \mathrm{L}$. RT-PCR was performed in a $10 \mu \mathrm{L}$ mixture containing $0.25 \mathrm{U}$ of the Blend taq polymerase (Toyobo), the reaction buffer for the Blend taq polymerase, $0.2 \mathrm{mM}$ dNTPs, and $0.2 \mu \mathrm{M}$ of forward and reverse primers. The primers used for each experiment are listed in Table S1. The RT-PCR products were then separated by electrophoresis on a $1.5 \%$ agarose gel and visualized by ethidium bromide staining.

\subsection{Inoculation Test}

Several attempts were made to transmit viruses from infected V. coignetiae to Nicotiana benthamiana and Solanum lycopersicum cv. Micro-tom. Mortar and pestle were used to grind infected leaf samples (500 mg) with $1 \mathrm{~mL}$ of $0.1 \mathrm{M}$ phosphate (pH 7.2), 0.1 M MES ( $\mathrm{pH}$ 5.5), or 0.1 M HEPES ( $\mathrm{pH} 7.8$ ) buffer containing $20 \mathrm{mM} \mathrm{Na}_{2} \mathrm{SO}_{3}, 10 \mathrm{mM}$ Na-DIECA, and $5 \mathrm{mM} \mathrm{Na}$-EDTA. The resulting inoculum was then inoculated into the first true leaf of a two-week-old seedling of $N$. benthamiana, and a one-week-old seedling of S. lycopersicum through mechanical rubbing with carborundum, after which plants were grown in a growth chamber $\left(25^{\circ} \mathrm{C}, 16 \mathrm{~h}\right.$ Photoperiod, $36 \mu \mathrm{mol} \cdot \mathrm{m}^{-2} \cdot \mathrm{s}^{-1}$. PPFD provided by a white fluorescent lamp). One month after inoculation, uninoculated upper leaves were collected, and total 
RNA was extracted as described earlier. Then, RT-PCR was conducted to check for viral infection, as described earlier.

\section{Results and Discussion}

\subsection{Identification of a Varicosavirus-Like Virus}

The genus Varicosavirus belongs to the family Rhabdoviridae, which classifies viruses with a diverse host range, including vertebrates, invertebrates, and plants [11]. The genome of the Rhabdoviridae consists of single-stranded (ss) negative-sense RNAs. At present, only one Varicosavirus, the lettuce big-vein associated varicosavirus (LBVaV) [12], has been listed by the International Committee on Taxonomy of Viruses (ICTV; https: / / talk.ictvonline.org/, accessed on 17 December 2020). Similarly, two tentative species, red clover-associated varicosavirus ( $\mathrm{RCaVV})$, and Alopecurus myosuroide varicosavirus 1 (AMVV1) have been reported $[13,14]$. All the aforementioned reports describe the genome of the Varicosavirus as a two-segmented RNA type.

Results of the BlastX search in this study are summarized in Table 2. Contig 38 in pool A (38A) indicated a 39.6\% identity with LBVaV (QBC40942.1). Additionally, the nucleotide sequence of $38 \mathrm{~A}$ indicated a $64.0 \%$ identity with a complete genome sequence of the RNA1 segment of RCaVV, as indicated by BlastN. Another $5535 \mathrm{nt}$ contig (85A) had the highest identity with the RNA2 segment of Rhabdovirus YHG-2013 (35.2\%), followed by LBVaV (QBC40942.1; 28.9\%) and AMVV1 (YP009130617.1, designated as a "Black grass varicosavirus-like virus" in the database; $27.0 \%$ ). It was, therefore, suggested that the twosegmented varicosavirus-like viruses be included in pool A. Thus, we provisionally named this putative virus as Vitis varicosavirus (VVV). Subsequently, we designed specific primer sets (Table S1) according to sequences of 38A and 85A contigs and conducted RT-PCR to confirm the VVV presence in V. coignetiae samples. The result indicated that two pool A samples were VVV-positive (Table 1). Partial sequences of RNA1 and RNA2 of VVV were then deposited in GenBank as LC604719 and LC604720, respectively.

ORF search in the proposed VVV partial genome identified one ORF in RNA1 and five ORFs in RNA2 (Figure 1a). In RNA1, the 2008 amino-acid (aa) protein with the expected molecular mass of $227 \mathrm{kDa}$, which had an RNA-dependent RNA polymerase (184-1057, Pfam: PF00946, $\left.1.6 \times 10^{-161}\right)$, mRNA-capping region V (1071-1287, Pfam: PF14318, $7.2 \times 10^{-18}$ ), and virus-capping methyltransferase (1618-1664, Pfam: PF14314, $0.19)$ motifs, was identified. The function of this $227.2 \mathrm{kDa}$ protein was proposed to be equivalent to that of the L-protein (LP) of other members of the Varicosavirus members [12-14].

Alternatively, in the proposed partial RNA2 genome, five ORFs encoding 425aa (48 kDa), 319aa (35 kDa), 344aa (38 kDa), 209aa (24 kDa), and 299aa (34 kDa) proteins (Figure 1a) were identified. The presence of these five ORFs in RNA2 of VVV was consistent with that of LBVaV [15], whereas RNA2 of RCaVV and AMVV1 had three ORFs [13,14]. The $48 \mathrm{kDa}$ protein shared a $47 \%$ identity with the nucleoprotein (a homolog of coat protein (CP)) of LBVaV (Q91QN9.1), whereas the $38 \mathrm{kDa}$ protein shared a $29 \%$ identity with Protein 3 of LBVaV (Q68Y30.1). Contrarily, BlastP analysis returned no significant results for the $35 \mathrm{kDa}, 24 \mathrm{kDa}$, and $34 \mathrm{kDa}$ proteins, whereas the MOTIF finder analysis also detected no motif in these three proteins (cutoff $\mathrm{E}$ value $\leq 0.1$ ). Thus, the function of these proteins remains uncharacterized. 
Table 2. Assembled contigs and related RNA segments of the three viruses detected in this study.

\begin{tabular}{|c|c|c|c|c|c|c|c|c|}
\hline Virus $^{a}$ & Genomic Segments & Contig No. ${ }^{b}$ & Length (nt) & No. of Reads & Best Much in BlastX & Query Coverage (\%) & Sequence Identity (\%) & $\begin{array}{c}\text { Accession Numbers } \\
\text { (NCBI, GenBank) }\end{array}$ \\
\hline \multirow{2}{*}{ VVV } & RNA1 & $38 \mathrm{~A}$ & 6450 & 19,629 & $\begin{array}{l}\text { Lettuce big-vein associated varicosavirus } \\
\text { [QBC40942.1] }\end{array}$ & 90 & 39.6 & LC604719 \\
\hline & RNA2 & $85 \mathrm{~A}$ & 5535 & 20,846 & $\begin{array}{c}\text { Black grass varicosavirus-like virus } \\
\text { [YP009130617.1] }\end{array}$ & 16 & 27.0 & LC604720 \\
\hline \multirow{9}{*}{ VEV } & RNA1a & $201 \mathrm{~A}$ & 7083 & 11,122 & $\begin{array}{c}\text { Aspen mosaic-associated virus } \\
\text { [CAA0079389.1] }\end{array}$ & 96 & 49.3 & LC604721 \\
\hline & RNA2a & $69 \mathrm{~A}$ & 2099 & 20,739 & $\begin{array}{c}\text { Pigeonpea sterility mosaic emaravirus } 2 \\
\text { [QBA83608.1] }\end{array}$ & 91 & 43.1 & LC604722 \\
\hline & RNA3b & $574 \mathrm{~A}$ & 881 & 308 & Fig mosaic emaravirus [AWS21340.1] & 91 & 44.4 & LC604732 \\
\hline & RNA4a & $184 \mathrm{~A}$ & 1270 & 574 & $\begin{array}{c}\text { Pigeonpea sterility mosaic emaravirus } 2 \\
\text { [ANQ90780.1] }\end{array}$ & 84 & 39.8 & LC604724 \\
\hline & RNA4b & $185 \mathrm{~A}$ & 1596 & 8948 & $\begin{array}{c}\text { Pigeonpea sterility mosaic emaravirus } 2 \\
\text { [ANQ90780.1] }\end{array}$ & 67 & 39.8 & LC604725 \\
\hline & RNA6a & $70 \mathrm{~A}$ & 1335 & 13,473 & Pistacia emaravirus [QAR18008.1] & 42 & 25.5 & LC604726 \\
\hline & RNA1b & $311 \mathrm{~B}$ & 7053 & 1149 & $\begin{array}{c}\text { Aspen mosaic-associated virus } \\
\text { [CAA0079389.1] }\end{array}$ & 97 & 48.9 & LC604727 \\
\hline & RNA2b & $179 \mathrm{~B}$ & 2091 & 1249 & $\begin{array}{c}\text { Pigeonpea sterility mosaic emaravirus } 2 \\
\text { [QBA83608.1] }\end{array}$ & 91 & 43.0 & LC604728 \\
\hline & RNA6b & $123 \mathrm{~B}$ & 1324 & 3090 & Pistacia emaravirus [QAR18008.1] & 38 & 25.3 & LC604731 \\
\hline \multirow{4}{*}{$\mathrm{VCV}$} & RNA1a & $369 \mathrm{~A}$ & 1563 & 1843 & Citrullus lanatus cryptic virus [APT68925.1] & 90 & 66.7 & LC602838 \\
\hline & RNA2a & $784 \mathrm{~A}$ & 1521 & 937 & Citrullus lanatus partitivirus [QLC27869.1] & 77 & 47.0 & LC602839 \\
\hline & RNA1b & $567 \mathrm{~B}$ & 1563 & 1349 & Citrullus lanatus cryptic virus [APT68925.1] & 90 & 65.6 & LC602840 \\
\hline & RNA2b & 146B & 1521 & 746 & Citrullus lanatus partitivirus [QLC27869.1] & 77 & 47.3 & LC602841 \\
\hline
\end{tabular}

a VVV: Vitis varicosavirus, VEV: Vitis emaravirus, VCV: Vitis cryptic virus. ${ }^{\mathrm{b}}$ Alphabets A and B that follow numbers indicate that the contig is pool A-derived and pool B-derived, respectively. 
(a)
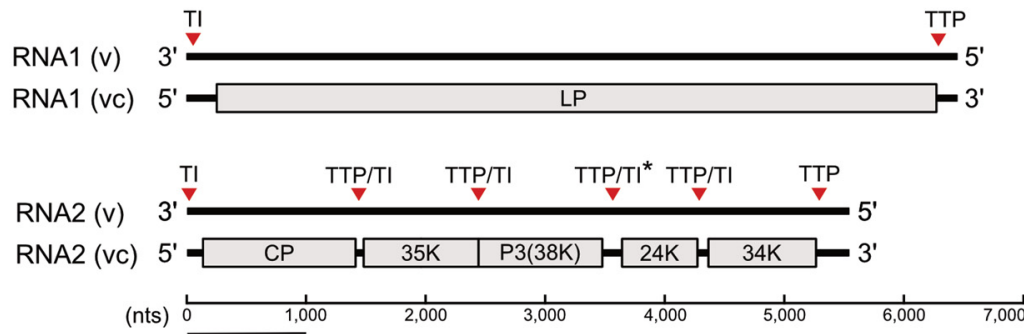

(b)

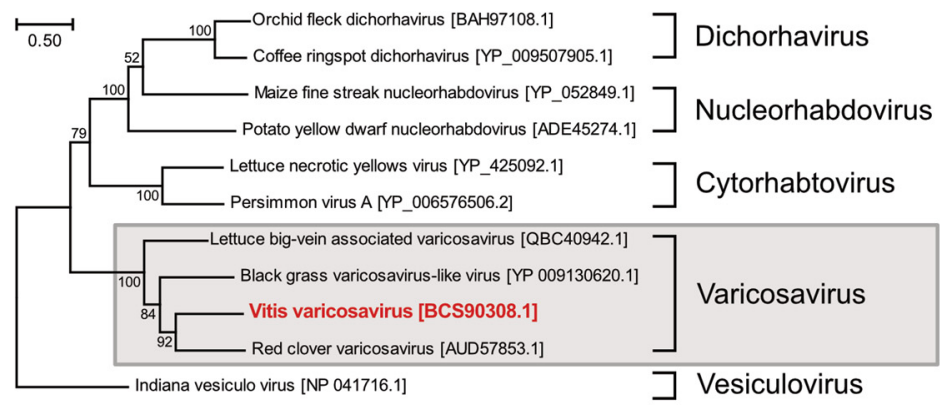

(C)

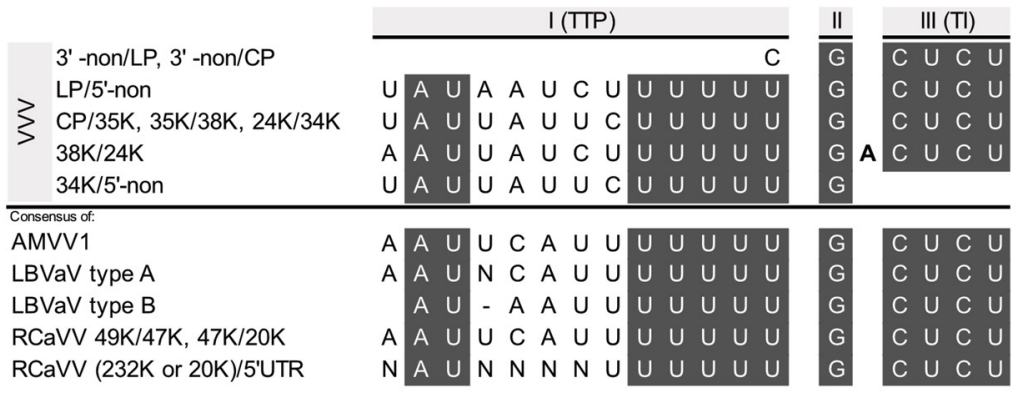

Figure 1. (a) Proposed genome organization of Vitis varicosavirus (VVV). In the negative-sense genome $(\mathrm{v})$, positions of identified transcription termination/polyadenylation (TTP) sites and transcription initiation (TI) sites are shown as red triangles. The asterisk indicates an additional A in the TI/TTP site. In the positive-sense strands (vc), open reading frames are presented as gray boxes. LP: Large protein, CP: Coat protein. (b) A phylogenetic tree showing the deduced amino-acid sequence of the partial LP gene of VVV showing its position with members of the genus Varicosavirus. The evolutionary history was inferred using the maximum likelihood method and the JTT matrix-based model. The tree with the highest $\log$ likelihood $(-53,228.85)$ is shown. The percentage of trees in which the associated taxa clustered together is also shown next to the branches. Initial tree(s) for the heuristic search were obtained automatically by applying Neighbor-Join and BioNJ algorithms to a matrix of pairwise distances estimated using the JTT model and then selecting the topology with superior log likelihood values. The tree is drawn to scale, with branch lengths measured in the number of substitutions per site. There were a total of 2308 positions in the final dataset. Indiana vesiculo virus was used as an outgroup. (c) Comparison of TI/TTP sites among VVV, LBVaV, and $\mathrm{RCaVV}$. Conserved motifs were shown as gray boxes with white letters. II: intergenic region.

Phylogenetic analysis based on the LP amino-acid sequences also supported the assignment of VVV into the Varicosavirus. Consistent with previous studies [14], AMVV1 and RCaVV made a subcluster within the Varicosavirus as well; thus, VVV was placed in this subcluster (Figure 1b). Similarly, CP of VVV showed the closest identity with that of RCaVV but was also close to that of LBVaV (Table 3). Therefore, when one considers the number of ORFs in RNA2 and the presence of putative homologous protein 3 in VVV and LBVaV but not in RCaVV and AMVV1, evolutional relations between these viruses are confusing. Further identification of novel Varicosavirus species should solve this situation. 
Table 3. Percent identity of the amino-acid sequence of the Vitis varicosavirus proteins with other varicosaviruses.

\begin{tabular}{|c|c|c|c|}
\hline & \multicolumn{3}{|c|}{ Vitis Varicosavirus (VVV) } \\
\hline & $\mathrm{LP}^{\mathrm{a}}$ & $\mathrm{CP}^{\mathrm{a}}$ & P3 ${ }^{a}$ \\
\hline Red clover varicosavirus $(\mathrm{RCaVV})$ & 40.9 & 30.1 & - \\
\hline Lettuce big-vein-associated varicosavirus (LBVaV) & 39.6 & 27.3 & 29.0 \\
\hline Alopecurus myosuroides varicosavirus 1 (AMVV1) & 38.6 & 27.0 & - \\
\hline
\end{tabular}

In the genome sequences of RNA1 and RNA2 of VVV, conserved gene junction sequence, which may be involved in transcription termination/polyadenylation (TTP) of upstream gene and transcription initiation (TI) of a downstream gene [11,16], was identified (Figure 1c). These junctions were located even up/downward of three uncharacterized genes. The sequences of the junctions matched well with those of AMVV1, LBVaV, and $\mathrm{RCaVV}$, only despite insertion of A between the intergenic and TI regions within $38 \mathrm{KDa} / 24 \mathrm{KDa}$ junctions (Figure 1c).

Based on the foregoing results, we propose that VVV is a new member of the genus Varicosavirus, in which two-segmented genomes encode the putative LP, CP, and four uncharacterized proteins.

\subsection{Identification of an Emaravirus-Like Virus}

The genus Emaravirus is the only clarified genus in the Fimoviridae family [17]. Since the first description of the European mountain ash ringspot-associated Emaravirus (EMARaV) in Sorbus aucuparia in 2007 [18], increasing numbers of Emaravirus have been reported [19]. The current ICTV taxonomy lists 11 species in Emaravirus, which are prevalent in fruit or ornamental trees and shrubs. The genome of Emaravirus also consists of four to eight segments of negative-sense ssRNAs. They are not capped or polyadenylated, and they contain 18-20 nt complementary sequences at the $5^{\prime}$ and $3^{\prime}$ termini [19].

Using Blast $X$ analysis, we found that some obtained contigs encoded proteins, which indicated some homology to that of Emaravirus proteins. Then, we used the Emaravirus genome dataset at NCBI (taxid: 675845) for customized local BlastX to detect emaraviruslike RNAs. All obtained contigs were then used as a query. Results indicated seven emaravirus-like contigs from pool A and five from pool B (Table 2). We also designed primer sets and checked the presence of these RNAs in V. coignetiae using RT-PCR. The results indicated that five and one samples, respectively, in pool A and B were positive. Note that in the positive samples, these five RNA segments could be detected without chipping (Figure S1). Furthermore, the sequencing of RNA3 and RNA4 amplicons from pool A revealed that there was a combination of $2 \mathrm{a}$ and $4 \mathrm{a}$ in no. 4, 5, and 6, as well as a combination of $2 b$ and $4 b$ in sample no. 17 (data not shown). From these, it was considered that the emaravirus-like virus, comprising at least five RNA segments, was present in these samples. Thus, we named this RNA set Vitis emaravirus (VEV). The proposed partial genome sequences were also deposited in GenBank (Table 1). In the following sections, we will focus on the genome set $(1 b, 2 b, 3 c, 4 c$, and $6 b)$ recovered from pool $B$.

ORF search within obtained segments of the VEV genome is summarized in Figure $2 \mathrm{a}$. RNA1b (311B) encodes a 2300aa protein with an estimated molecular mass of $269 \mathrm{kDa}$, which had a $48.9 \%$ identity with RdRp of the aspen mosaic-associated virus (CAA0079389.1), a provable member of the Emaravirus family, found in Populus tremula [20]. Motif analysis within this protein was identified as a Bunyavirus RdRp motif (646-1389; Pfam: PF04196; $3.8 \times 10^{-54}$ ), suggesting that this protein was orthologous to the conserved RdRp members of Fimoviridae. Similarly, RNA1a (201A) encodes the 2300aa protein, which has a $97.4 \%$ identity with that of 311B, and the Bunyavirus RdRp motif (Pfam: PF04196) that was conserved. 

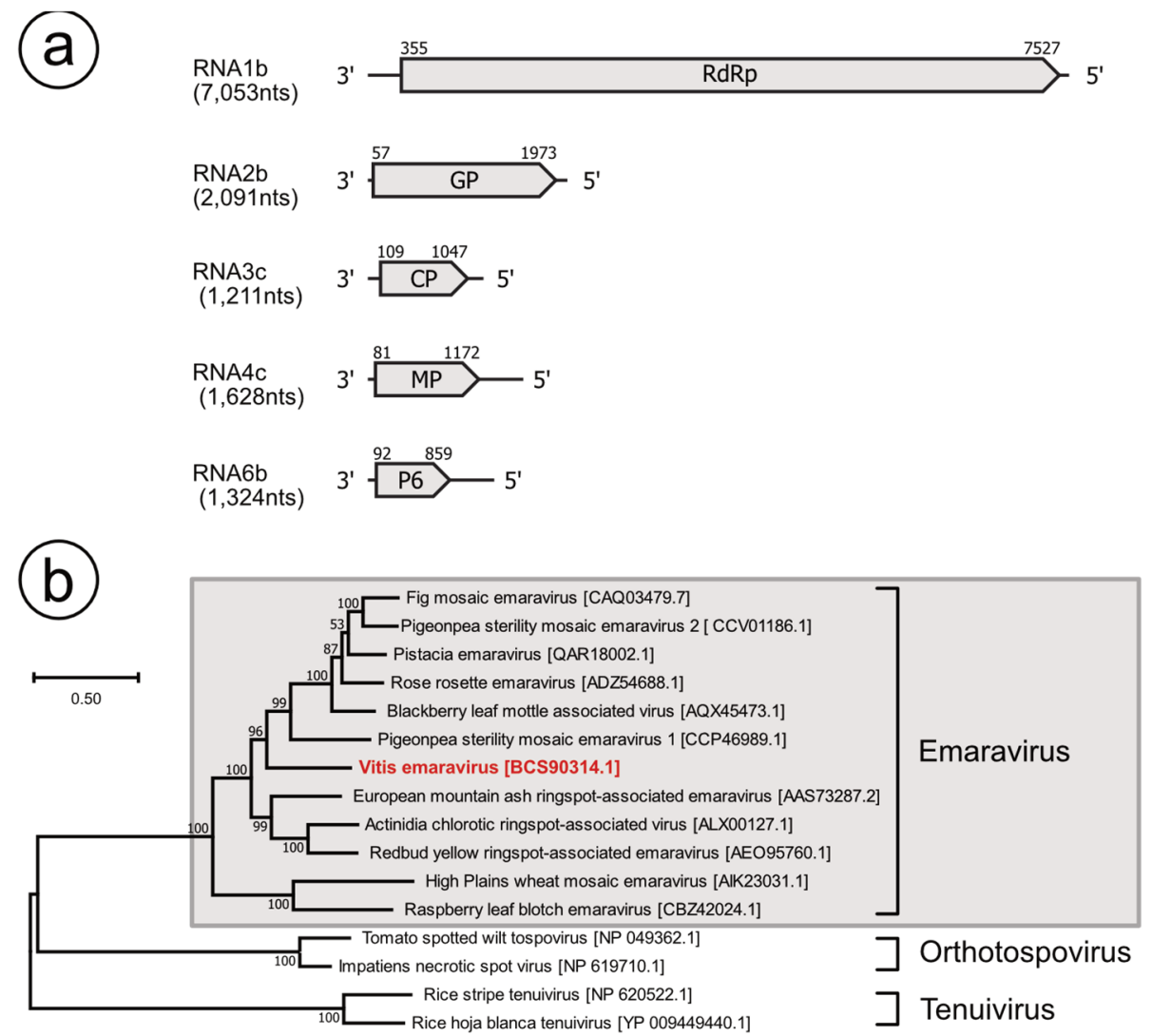

Figure 2. (a) Proposed genome organization of Vitis emaravirus (VEV). Genome segments of the negative-sense RNA virus are displayed as mRNAs with the encoded open reading frames as gray arrows. RdRp: RNA-dependent RNA polymerase, GP: glycoprotein precursor, CP: coat protein, MP: movement protein. (b) Phylogenetic tree showing the deduced amino-acid sequence of the partial RdRp gene of VEV showing its position with members of the Emaravirus genus. The evolutionary history was inferred using the maximum likelihood method and the JTT matrix-based model. The tree with the highest log likelihood $(-71,655.15)$ is also shown. The percentage of trees in which the associated taxa are clustered together is shown next to the branches as well. Initial tree(s) for the heuristic search were obtained automatically by applying Neighbor-Join and BioNJ algorithms to a matrix of pairwise distances estimated using the JTT model and then selected using the topology with a superior log likelihood value. The tree is drawn to scale, with branch lengths measured in the number of substitutions per site. There were 3370 positions in the final dataset.

RNA2b (179B) encoded a putative glycoprotein precursor (GP) in length 638aa (73 kDa), which had $43.0 \%$ identity with GP of pigeon-pea-sterility mosaic emaravirus 2 (PPSMV2; QBA83608), a provable member of Emaravirus found in Cajanu cajin [21]. In silico analysis of putative GP indicated three putative transmembrane helices at positions aa 5-27, 174-191, and 581-603 and five predicted N-glycosylation sites at aa 69, 205, 243, 332, and 439. We could not detect potential cleavage sites using SignalP analysis. However, the tetra peptide ADDN $_{193-196}$ was present, which might produce $22 \mathrm{kDa}\left(\mathrm{G}_{\mathrm{n}}\right)$ and $50 \mathrm{kDa}\left(\mathrm{G}_{\mathrm{c}}\right)$, as described in other emaraviruses $[18,22,23]$. RNA2a (69A) encodes 638 aa putative GP, which is $98.10 \%$ identical to that in RNA2b. In silico analyses returned similar results.

RNA3c (58B) encoded a 312aa protein (35 kDa), which had a $44.1 \%$ identity with that of CP of the fig mosaic virus (FMV; CAA0079389.1), which is an approved member of Emaravirus found in Ficus carica [22,24]. In CPs of Emaravirus, two conserved aminoacid blocks $\left(\mathrm{NX}_{2} \mathrm{SXNX}_{3} \mathrm{~A}\right.$ and NXLA), which are potential nucleocapsid motifs have been reported $[22,23,25]$. The $35 \mathrm{kDa}$ VEV protein was also posed as an NXLA197-200 motif, but instead of the $\mathrm{NX}_{2} \mathrm{SXNX}_{3} \mathrm{~A}$ motif, EFVSFNKA $148-157$ was observed (Figure S2). Although there was a substitution of $\mathrm{N}$ by E, EFVSFNKA $148-157$, and putative nucleocapsid motif 
NXLA $197-200$, were aligned clearly along with those in other emaraviruses. Therefore, we considered that $35 \mathrm{kDa}$ was that of CP of VEV. Similarly, RNA3a (19A) encoded the 312aa protein, which is perfectly identical to that of RNA3c. Contig 574A was shorter than those of $19 \mathrm{~A}$ and $58 \mathrm{~B}$, and ORF in length 270aa, which lacked 42 residues in the $\mathrm{C}$ termini was observed as well. Additionally, in 270aa, 10 residues were different from those of 312aa in 19A and 58B, but EFVSFNKA $148-157$ and NXLA $197-200$ motifs remained conserved.

Additionally, RNA4c encoded 363aa proteins $(41 \mathrm{kDa})$ with $39.5 \%$ identity with the movement protein (MP) of PPSMV2 (ANQ90753.1). This $41 \mathrm{kDa}$ was also recognized as belonging to the Emaravirus_P4 super family (42-361, Pfam: 16505, $\left.1.1 \times 10^{-88}\right)$, thus sharing the MP function. The ORF finder also indicated that RNA4a and RNA4b encoded $343 \mathrm{aa}$ (39 kDa) identical proteins, which also posed as the Emaravirus_P4 super family motif. The 343aa in RNA4a and RNA4b showed high identity with the $41 \mathrm{kDa}$ of RNA4c, and only two amino-acid changes were found. However, they lacked 17 amino-acid residues in the $\mathrm{N}$ terminus compared to that of the $41 \mathrm{kDa}$ of RNA4c; thus, they were considered to be partial CDS of MP.

The last segment, 123B encodes 255aa proteins (29 kDa), having 25.3\% identity with Protein 6 (P6) of pistacia emaravirus (PiVB; QAR18008.1), a provable member of Emaravirus found in Pistacia spp. [26]. Although the identity between this $29 \mathrm{kDa}$ and P6 of PiVB was low, and the function of this $29 \mathrm{kDa}$ protein could not be estimated by the MOTIF finder, P6 of PiVB was the only significant result obtained using BlastP (Query cover: 66\%; E value: $1.0 \times 10^{-5}$ ). Thus, we considered that this segment was homologous to RNA6 of PiVB. Amino-acid comparison between P6 among emaraviruses also indicated that VEV had an identity of $11.2-23.4 \%$ with known emaraviruses (Table 4). Contig $70 \mathrm{~A}$ also encoded 255 aa proteins, with an amino-acid sequence of $98.4 \%$ identity to that of $123 \mathrm{~B}$. With the fact that this putative RNA6 could be detected in VEV-positive samples but not in VEV negative samples (Figure S1), we concluded that it was a component of the VEV genome. The segment homologous to RNA5 of other emaraviruses could not be found in this study.

Table 4. Percent identity of amino-acid sequence of Vitis emaravirus with other emaraviruses.

\begin{tabular}{|c|c|c|c|c|c|}
\hline \multirow[b]{2}{*}{ Virus } & \multicolumn{5}{|c|}{ Vitis Emaravirus (VEV) } \\
\hline & $\begin{array}{c}\text { RdRp } \\
\text { [GenBank] }\end{array}$ & $\begin{array}{c}\text { GP } \\
{[\text { GenBank] }}\end{array}$ & $\begin{array}{c}\text { CP } \\
{[\text { GenBank] }}\end{array}$ & $\begin{array}{c}\text { MP } \\
{[\text { GenBank] }}\end{array}$ & $\begin{array}{c}\text { P6 } \\
{[\text { GenBank] }}\end{array}$ \\
\hline Pistacia emaravirus & $\begin{array}{c}48.9 \\
\text { [QAR18002.1] }\end{array}$ & $\begin{array}{c}39.3 \\
{[Q A R 18003.1]}\end{array}$ & $\begin{array}{c}38.6 \\
{[Q A R 18004.1]}\end{array}$ & $\begin{array}{c}35.0 \\
{[Q A R 18005.1]}\end{array}$ & $\begin{array}{c}22.6 \\
\text { [QAR18008.1] }\end{array}$ \\
\hline $\begin{array}{c}\text { Pigeonpea sterility mosaic } \\
\text { emaravirus } 2\end{array}$ & $\begin{array}{c}48.6 \\
{[C C V 01186.1]}\end{array}$ & $\begin{array}{c}42.1 \\
\text { [YP_009268865.1] }\end{array}$ & $\begin{array}{c}40.3 \\
\text { [YP_009268864.1] }\end{array}$ & $\begin{array}{c}37.4 \\
\text { [YP_009268866.1] }\end{array}$ & $\begin{array}{c}21.0 \\
\text { [YP_009268862.1] }\end{array}$ \\
\hline $\begin{array}{c}\text { Pigeonpea sterility mosaic } \\
\text { emaravirus } 1\end{array}$ & $\begin{array}{c}48.3 \\
{[\mathrm{CCP} 46989.1]}\end{array}$ & $\begin{array}{c}39.7 \\
\text { [YP 009237263.1] }\end{array}$ & $\begin{array}{c}38.0 \\
\text { [YP 009237281.1] }\end{array}$ & - a & 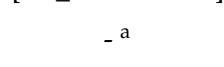 \\
\hline $\begin{array}{l}\text { Blackberry leaf } \\
\text { mottle-associated virus }\end{array}$ & $\begin{array}{c}48.2 \\
{[A Q X 45473.1]}\end{array}$ & $\begin{array}{c}40.1 \\
\text { [AQX45474.1] }\end{array}$ & $\begin{array}{c}38.3 \\
{[A Q X 45475.1]}\end{array}$ & $\begin{array}{c}37.4 \\
{[\mathrm{AQX} 45476.1]}\end{array}$ & $-a$ \\
\hline $\begin{array}{l}\text { Redbud yellow } \\
\text { ringspot-associated emaravirus }\end{array}$ & $\begin{array}{c}48.0 \\
{[\mathrm{AEO} 95760.1]}\end{array}$ & $\begin{array}{c}39.2 \\
{\left[Y P \_009508087.1\right]}\end{array}$ & $\begin{array}{c}32.7 \\
\text { [YP_009508085.1] }\end{array}$ & $\begin{array}{c}23.4 \\
{\left[Y P \_009508084.1\right]}\end{array}$ & $-{ }^{a}$ \\
\hline Fig mosaic emaravirus & $\begin{array}{c}48.0 \\
{[C A Q 03479.7]}\end{array}$ & $\begin{array}{c}40.8 \\
{\left[Y P \_009237272.1\right]}\end{array}$ & $\begin{array}{c}40.5 \\
\text { [YP_009237270.1] }\end{array}$ & $\begin{array}{c}36.3 \\
{\left[Y P \_009237271.1\right]}\end{array}$ & $\begin{array}{c}14.3 \\
{\left[Y P \_009237275.1\right]}\end{array}$ \\
\hline $\begin{array}{l}\text { European mountain ash } \\
\text { ringspot-associated emaravirus }\end{array}$ & $\begin{array}{c}47.9 \\
{[\mathrm{AAS} 73287.2]}\end{array}$ & $\begin{array}{c}36.4 \\
{\left[Y P \_003104765.1\right]}\end{array}$ & $\begin{array}{c}36.6 \\
\text { [YP_003104767.1] }\end{array}$ & $\begin{array}{c}7.7 \\
\text { [YP_003104766.1] }\end{array}$ & L- - \\
\hline Rose rosette emaravirus & $\begin{array}{c}47.9 \\
{[\mathrm{ADZ} 54688.1]}\end{array}$ & $\begin{array}{c}41.2 \\
\text { [YP_004327590.1] }\end{array}$ & $\begin{array}{c}35.8 \\
\text { [YP_004327591.1] }\end{array}$ & $\begin{array}{c}36.6 \\
\text { [YP_004327592.1] }\end{array}$ & $\begin{array}{c}20.8 \\
\text { [YP_009380548.1] }\end{array}$ \\
\hline $\begin{array}{l}\text { Actinidia chlorotic } \\
\text { ringspot-associated virus }\end{array}$ & $\begin{array}{c}47.8 \\
{[\mathrm{ALX} 00127.1]}\end{array}$ & [YP_009507926.1] & $\begin{array}{c}34.6 \\
\text { [YP_009507928.1] }\end{array}$ & $\begin{array}{c}25.1 \\
\text { [YP_009507927.1] }\end{array}$ & $-a$ \\
\hline $\begin{array}{c}\text { Raspberry leaf blotch } \\
\text { emaravirus }\end{array}$ & $\begin{array}{c}32.4 \\
{[\mathrm{CBZ} 42024.1]}\end{array}$ & $\begin{array}{c}21.0 \\
\text { [YP_009237265.1] }\end{array}$ & $\begin{array}{c}18.7 \\
\text { [YP_009237266.1] }\end{array}$ & $\begin{array}{c}17.6 \\
\text { [YP_009237267.1] }\end{array}$ & $\begin{array}{c}11.6 \\
\text { [YP_009237278.1] }\end{array}$ \\
\hline $\begin{array}{c}\text { High Plains wheat mosaic } \\
\text { emaravirus }\end{array}$ & $\begin{array}{c}30.2 \\
{[\mathrm{AIK} 23031.1]}\end{array}$ & $\begin{array}{c}21.0 \\
{\left[Y P \_009237256.1\right]}\end{array}$ & $\begin{array}{c}18.3 \\
\text { [YP_009237257.1] }\end{array}$ & $\begin{array}{c}18.6 \\
\text { [YP_009237258.1] }\end{array}$ & $\begin{array}{c}11.4 \\
\text { [YP_009237260.1] }\end{array}$ \\
\hline
\end{tabular}

${ }^{a}$ Homologous protein sequences were not available in the NCBI database. 
Tatineni et al. [27] demonstrated that the phylogenetic tree based on the RdRp sequence represented three subclusters within the Emaravirus genus. This picture was repeatedly confirmed by other studies $[23,25,26,28]$. Consistent with previous studies, our phylogenetic analysis depicted subclusters, including FMV, PPSMV2, PiBV, rose rosette emaravirus, blackberry leaf mottle-associated virus, PPSMV1 (designated as subclade A by Zheng et al. [25]), subcluster B, including EMARaV, actinidia chlorotic ringspot-associated emaravirus, and redbud yellow ringspot-associated emaravirus, subcluster $\mathrm{C}$, including high plains wheat mosaic virus and raspberry leaf blotch emaravirus, in the Emaravirus genus (Figure 2b). VEV also created a new branch of subcluster A with a high-bootstrap value support. Amino-acid comparison of RdRp among the Emaraviruses supported that VEV had relatively higher identity, 47.7-49.1\%, with members of subclusters A and B as well, compared to those of the other two viruses in subcluster $C$ (Table 4). A similar tendency was observed for GP, CP, and MP.

Based on the foregoing results, we propose that VEV is a new member of the genus Emaravirus. VEV was consistent with at least five-segmented genomes, which encoded putative RdRp, GP, NP, P3, and one uncharacterized protein. Although the possibility of the presence of other segments of VEV could not be denied, the genome set of detected VEV satisfied the minimal composition of known emaraviruses.

\subsection{Identification of Partitivirus-Like Virus}

The genome of members of the Partiviridae family was consistent for two- to threesegmented double-stranded (ds) RNAs, which were encapsulated individually to make biparticulate virions [29]. Segments encoded by RdRp were also designated as dsRNA1, and the segment encoded by $\mathrm{CP}$ was designated as dsRNA2, respectively. The family has host ranges in fungi, plants, and protozoa. The current ICTV taxonomy also puts five genera in this family: Alphapartitivirus, Betapartitivirus, Cryspovirus, Gammapartitivirus, and Deltapartitivirus. At present, both plant and fungal viruses are listed in Alphapartitivirus and Betapartitivirus. Alternatively, Gammapartitivirus and Deltapartitivirus include only fungal and plant viruses, respectively [30,31]. Similarly, the Cryspovirus genus also currently contains only one protozoal virus, Cryptosporidium parvum virus 1 , isolated from Cryptosporidium [32].

We found that 1563 and $1521 \mathrm{nt}$ contigs from pool A (369A and 784A) and 1563 and $1521 \mathrm{nt}$ contigs from pool B (567B and 146B) had some homology to the Partitiviridae genome (Table 2). Pairwise alignment by needle also indicated that the nucleotide sequence of 369A and 567B had a 95.8\% identity, whereas 784A and 146B had $97.7 \%$ identities, respectively. It was, therefore, suggested that the partitivirus-like virus infected both pool A and B samples, but infecting strains in pools A and B, respectively, were different. We provisionally named this putative virus as Vitis cryptic virus (VCV) and proposed a partial genome sequence that we deposited in GenBank (Table 1).

The proposed partial genome of VCV is as drawn in Figure 3a. The ORF search identified a single ORF in each segment. RNA1a (369A; LC602838) encoded a 478aa (54 kDa) protein with viral RNA-dependent RNA polymerase (38-454, Pfam: PF00680, $9.7 \times 10^{-72}$ ) and viral RNA-directed polymerase (192-365, Pfam: PF02123, $\left.1.4 \times 10^{-5}\right)$, which has a $66.7 \%$ identity with RdRp of the citrullus lanatus cryptic virus (CiLCV; APT68925.1), a provable member of Deltapartitivirus identified in watermelon [33,34]. This protein also has 65.7\% identity with RdRp of pepper cryptic virus 1 (PepCV1; AYA43794.1), a type species of Deltapartitivirus. Similarly, RNA1b (567B; LC602840) posed one ORF, which encodes 478aa putative RdRp showing $95.8 \%$ identity with that of RNA1a. 
(a)

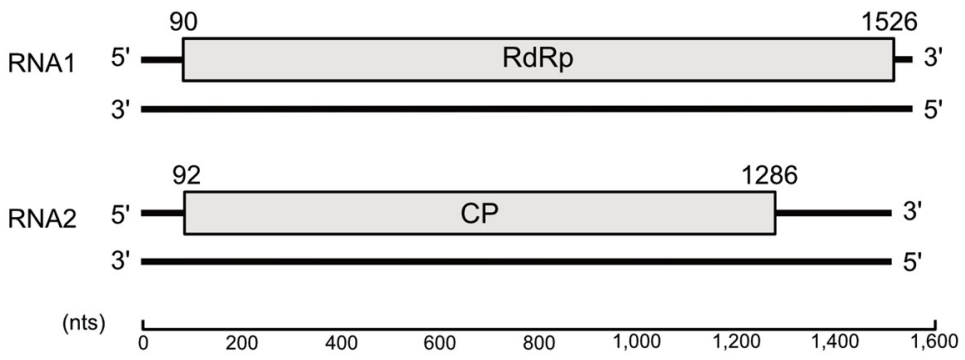

(b)

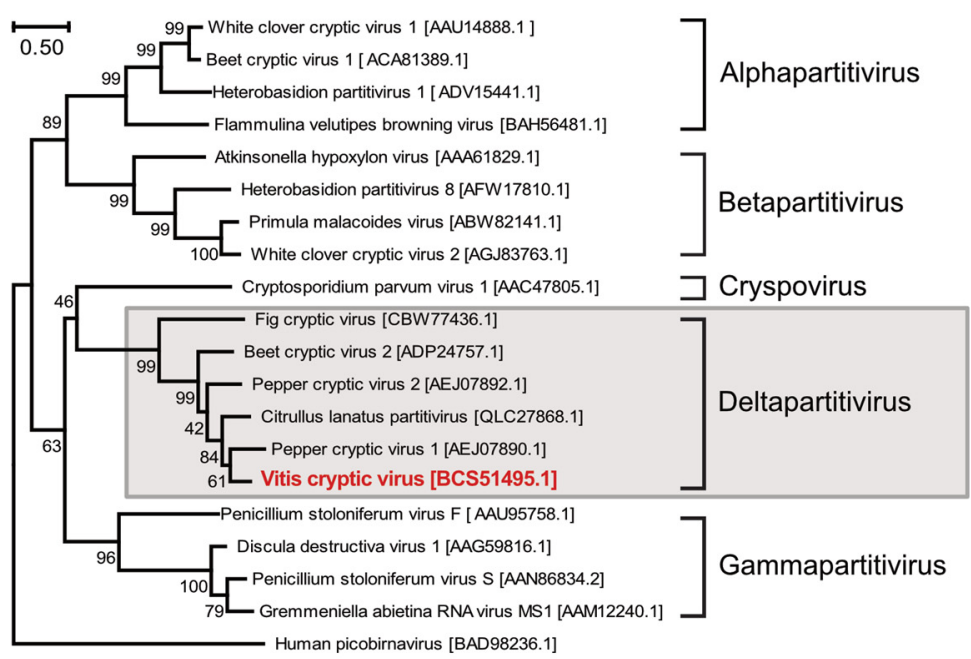

Figure 3. (a) Proposed partial genome organization of Vitis cryptic virus (VCV). Open reading frames are presented as gray boxes. RdRp: RNA-dependent RNA polymerase, CP: Coat protein. Numbers above gray boxes indicate start/end nucleotide positions of open reading frames. (b) Phylogenetic tree showing the deduced amino-acid sequence of the RdRp gene of VCV showing its position with members of the Deltapartitivirus genus. The evolutionary history was inferred using the maximum likelihood method and the JTT matrix-based model. The tree with the highest log likelihood $(-23,194.31)$ is as presented. Percentages of trees in which the associated taxa clustered together are shown next to the branches. Initial tree(s) for the heuristic search were obtained automatically by applying Neighbor-Join and BioNJ algorithms to a matrix of pairwise distances estimated using the JTT model and then selecting the topology with superior log likelihood values. The tree is drawn to scale, with branch lengths measured in the number of substitutions per site. There were 841 positions in the final dataset. The human picobirna virus was used as an outgroup.

RNA2a (784A; LC602839) encoded a 397aa protein (46 kDa), which had a $47.5 \%$ identity with CP of CiLCV (QLC27869.1). Then, alignment of this putative $46 \mathrm{kDa}$ putative $\mathrm{CP}$ and $\mathrm{CPs}$ in the other five approved deltapartitivirus (FMV, PepCV1, PepCV2, beet cryptic virus 2 (BCV2), and BCV 3) were performed. Without the $46 \mathrm{kDa}$ of VCV, amino acids were identical at 14 positions, and adding the $46 \mathrm{kDa}$ protein to them reduced the identical points to 11 positions (data not presented). Low aa sequence identities among CPs in partitiviruses were reported previously $[35,36]$, which suggests that partitivirus CPs had higher evolution rates than those in RdRps [35]. Similarly, RNA2b (146B; LC602841) posed one of the ORFs, which encodes the 397aa putative RdRp, showing $98.2 \%$ identity with that in RNA2a.

Phylogenetic analyses based on the RdRp amino-acid sequence also showed that this virus was clustered into the genus Deltapartitivirus (Figure 3b), in which all approved members are plant viruses. Comparison of the genome sequence and the amino-acid sequence of RdRps and CPs with other approved Deltapartitivirus and CiLCV and type species in Alphapartitivirus, Betapartitivirus, and Gammapartitivirus are presented in Table 5. The RdRp and CP of VCV also had the highest similarity with CiLCV, followed by PepCV1. 
Consistent with phylogenetic trees based on RdRps, alignment of CPs to VCV, PepCV1, PepCV2, and CiLCV indicated 74 identical positions and some conserved blocks, which could not be recognized with FMV, BCV2, and BCV3, as described earlier (Figure S3). These suggested relatively close relationships among VCV, PepCV1, PepCV2, and CiLCV in deltapartitiviruses.

Table 5. Percent identity of protein sequence of Vitis cryptic virus with other Partitiviridae.

\begin{tabular}{|c|c|c|c|}
\hline \multirow{2}{*}{ Genus } & \multirow{2}{*}{ Virus } & \multicolumn{2}{|c|}{ Vitis Cryptic Virus (Pool A;BCS51495.1/BCS51469.1) } \\
\hline & & RdRp [GenBank] & CP [GenBank] \\
\hline \multirow{6}{*}{ Deltapartitivirus } & Vitis cryptic virus (Pool B) & 95.8 [BCS51497.1] & 98.2 [BCS51498.1] \\
\hline & Citrulluslanatus partitivirus & 66.7 [АРТ68925.1] & 47.5 [QLC27869.1] \\
\hline & Pepper cryptic virus 1 & 65.7 [QEO60284.1] & 39.7 [AVV48359.1] \\
\hline & Pepper cryptic virus 2 & 59.9 [AVL84364.1] & 37.9 [ALR34989.1] \\
\hline & Beet cryptic virus 2 & 58.6 [QCF59322.1] & 32.6 [QCF59321.1] \\
\hline & Fig cryptic virus & $37.7[\mathrm{CBZ05548.1]}$ & 18.7 [YP_004429259.1] \\
\hline Alphapartitivirus & White clover cryptic virus 1 & 19.6 [YP_086754.1] & $4.5\left[\mathrm{YP} \_086755.1\right]$ \\
\hline Betapartitivirus & Atkinsonella hypoxylon virus & $18.1\left[N P \_604475.1\right]$ & $14.0\left[N P \_604476.1\right]$ \\
\hline Crypsovirus & Cryptosporidium parvum virus 1 & 21.3 [YP_009508065.1] & 16.8 [YP_009508066.1] \\
\hline Gammapartitivirus & Penicillium stoloniferum virus S & 19.7 [YP_052856.2] & 1.8 [YP_052857.1] \\
\hline
\end{tabular}

Based on the foregoing results, we propose that VCV is a new member of the genus Deltapartitivirus, which is consistent with the two-segmented genome encoding $\mathrm{RdRp}$ and CP.

\subsection{Mix Infection Status in V. coignetiae}

Blast $X$ search revealed two contigs having high homology with the grapevine Pinot gris virus (GPGV). Infection of GPGV (LC601811 and LC601812) in collected materials was confirmed previously [37]. Additionally, there are two contigs with high homology with the grapevine berry inner necrosis virus (GINV). A nucleotide sequence of $7106 \mathrm{nt}$ (LC605829) and $7204 \mathrm{nt}$ (LC605830) contigs also indicated 78.6\% and 79.3\% identity with reported GINV sequence (D88448.2), as indicated by BlastN. LC605829 poses of ORFs encoded RdRp, MP, and partial CP, whereas LC605830 poses completely that of RdRp, MP, and CP. BlastP analysis also indicated that RdRp and MP in LC605829 had an 84.4\% and 86.3\% identity, respectively, with those of known amino-acid sequences (YP_004293216.1 and YP_004293217.1), whereas RdRp, CP, and MP in LC605830 had 84.6\%, 88.3\%, and 94.4\% identity with YP_004293216.1, YP_004293217.1, and APT43224.1. GPGV [38] and GINV [39] are members of the Trichovirus genus in the Triviridae family. Trichovirus has a monopartite, positive-sense ssRNA, which encodes up to six ORFs [40]. Among these, 34 samples were used, and 12 samples were mix-infected by up to four viruses (Table 1). Presented data indicate the mix infection status by a wide range of RNA viruses in wild $V$. coignetiae habited in Japan. There were no plant materials, which showed obvious symptoms with single viral infections. Thus, we could not characterize symptoms caused by these viruses in V. coignetiae. Pictures of observed symptomatic leaves are available in Figure S4. Since we collected all materials from natural woods in rural areas, apart from commercial vine fields, graft transmission of the virome from commercial grapevine was unlikely. It is presumed that the viruses most have become infected by a vector over time and the diversity is the result of recombination and mutations.

\subsection{Inoculation Test}

Based on previous studies on LBVaV [12], we prepared three types of inoculum using three different buffers. The leaf used for inoculation was sample no. 1, which was infected by VVV, GPGV, and GINV (Table 1). Regardless of the buffer used for preparation, the resulting inoculum did not induce infection of tested viruses to S. lycopersicum and $N$. benthamiana (data not presented). 


\section{Conclusions}

HTS in V. coignetiae identified three novel viruses: Vitis varicosavirus, Vitis emaravirus, and Vitis cryptic virus. From our findings, we conclude that each virus should be assigned to the Varicosavirus, Emaravirus, and Deltapartitivirus genera, respectively. To the best of our knowledge, this is the first identification of these three genera in the Vitis family.

Supplementary Materials: The following are available online at https:/ / www.mdpi.com/article/10 $.3390 / v 13050827$ /s1, Figure S1: Analysis of viral infections in Vitis coignetiae, Figure S2: Alignment of coat protein amino-acid sequence among Vitis emaravirus and other approved Emaravirus, Figure S3: Alignment of the coat protein amino-acid sequence among Vitis cryptic virus and other Partitiviridae, Figure S4: Some Vitis coignetiae samples used in this study showed viral-like mosaic symptoms, Table S1: Primer sequences used in this study.

Author Contributions: T.N. designed the work, analyzed the data and draft the manuscript. J.A. designed the work, collected samples and conducted experiments. All authors have read and agreed to the published version of the manuscript.

Funding: This work was supported by JSPS KAKENHI Grant Numbers 18K14457 and 21K14846.

Institutional Review Board Statement: Not applicable.

Informed Consent Statement: Not applicable.

Data Availability Statement: The sequence data have been submitted to the DDBJ/EMBL/GenBank databases under accession number LC602838-602841, LC604719-604732 and LC601811-601812. Addresses are as follows: GenBank http:/ / www.ncbi.nlm.nih.gov.

Acknowledgments: We thank Daiki Matsumoto at Fukui Prefectural University for kind assistance and useful suggestions for sequence data analysis.

Conflicts of Interest: The authors declare no conflict of interest.

\section{References}

1. Massart, S.; Candresse, T.; Gil, J.; Lacomme, C.; Predajna, L.; Ravnikar, M.; Reynard, J.S.; Rumbou, A.; Saldarelli, P.; Škoric, D.; et al. A framework for the evaluation of biosecurity, commercial, regulatory, and scientific impacts of plant viruses and viroids identified by NGS technologies. Front. Microbiol. 2017, 8. [CrossRef] [PubMed]

2. Roossinck, M.J. Deep sequencing for discovery and evolutionary analysis of plant viruses. Virus Res. 2017, 239, 82-86. [CrossRef] [PubMed]

3. Massart, S.; Olmos, A.; Jijakli, H.; Candresse, T. Current impact and future directions of high throughput sequencing in plant virus diagnostics. Virus Res. 2014, 188, 90-96. [CrossRef]

4. Martin, R.R.; Constable, F.; Tzanetakis, I.E. Quarantine Regulations and the Impact of Modern Detection Methods. Annu. Rev. Phytopathol. 2016, 54, 189-205. [CrossRef] [PubMed]

5. Wan, Y.; Schwaninger, H.R.; Baldo, A.M.; Labate, J.A.; Zhong, G.Y.; Simon, C.J. A phylogenetic analysis of the grape genus (Vitis L.) reveals broad reticulation and concurrent diversification during neogene and quaternary climate change. BMC Evol. Biol. 2013, 13. [CrossRef] [PubMed]

6. Umer, M.; Liu, J.; You, H.; Xu, C.; Dong, K.; Luo, N.; Kong, L.; Li, X.; Hong, N.; Wang, G.; et al. Genomic, morphological and biological traits of the viruses infecting major fruit trees. Viruses 2019, 11, 515. [CrossRef] [PubMed]

7. Okamoto, G.; Ueki, K.; Ichi, T.; Aoki, H.; Fujiwara, M.; Hirano, K. Juice constituents and skin pigments in Vitis coignetiae Pulliat grapevines. Vitis 2002, 41, 161-162.

8. Yun, J.W.; Lee, W.S.; Kim, M.J.; Lu, J.N.; Kang, M.H.; Kim, H.G.; Kim, D.C.; Choi, E.J.; Choi, J.Y.; Kim, H.G.; et al. Characterization of a profile of the anthocyanins isolated from Vitis coignetiae Pulliat and their anti-invasive activity on HT-29 human colon cancer cells. Food Chem. Toxicol. 2010, 48, 903-909. [CrossRef]

9. Kumar, S.; Stecher, G.; Li, M.; Knyaz, C.; Tamura, K. MEGA X: Molecular Evolutionary Genetics Analysis across Computing Platforms. Mol. Biol. Evol. 2018, 35, 1547-1549. [CrossRef]

10. Jones, D.T.; Taylor, W.R.; Thornton, J.M. The rapid generation of mutation data matrices from protein sequences. Bioinformatics 1992, 8, 275-282. [CrossRef]

11. Dietzgen, R.G.; Kondo, H.; Goodin, M.M.; Kurath, G.; Vasilakis, N. The family Rhabdoviridae: Mono- and bipartite negative-sense RNA viruses with diverse genome organization and common evolutionary origins. Virus Res. 2017, 227, 158-170. [CrossRef]

12. Verbeek, M.; Dullemans, A.M.; van Bekkum, P.J.; van der Vlugt, R.A.A. Evidence for Lettuce big-vein associated virus as the causal agent of a syndrome of necrotic rings and spots in lettuce. Plant Pathol. 2013, 62, 444-451. [CrossRef] 
13. Sabbadin, F.; Glover, R.; Stafford, R.; Rozado-Aguirre, Z.; Boonham, N.; Adams, I.; Mumford, R.; Edwards, R. Transcriptome sequencing identifies novel persistent viruses in herbicide resistant wild-grasses. Sci. Rep. 2017, 7, 1-8. [CrossRef]

14. Koloniuk, I.; Fránová, J.; Sarkisova, T.; Přibylová, J.; Lenz, O.; Petrzik, K.; Špak, J. Identification and molecular characterization of a novel varicosa-like virus from red clover. Arch. Virol. 2018, 163, 2213-2218. [CrossRef]

15. Sasaya, T.; Kusaba, S.; Ishikawa, K.; Koganezawa, H. Nucleotide sequence of RNA2 of Lettuce big-vein virus and evidence for a possible transcription termination/initiation strategy similar to that of rhabdoviruses. J. Gen. Virol. 2004, 85, $2709-2717$. [CrossRef]

16. Rose, J.K. Complete intergenic and flanking gene sequences from the genome of vesicular stomatitis virus. Cell 1980, $19,415-421$. [CrossRef]

17. Elbeaino, T.; Digiaro, M.; Mielke-Ehret, N.; Muehlbach, H.P.; Martelli, G.P. ICTV virus taxonomy profile: Fimoviridae. J. Gen. Virol. 2018, 99, 1478-1479. [CrossRef]

18. Mielke, N.; Muehlbach, H.P. A novel, multipartite, negative-strand RNA virus is associated with the ringspot disease of European mountain ash (Sorbus aucuparia L.). J. Gen. Virol. 2007, 88, 1337-1346. [CrossRef]

19. Mielke-Ehret, N.; Mühlbach, H.P. Emaravirus: Anovel genus of multipartite, negative strand RNA plant viruses. Viruses 2012, 4 , 1515-1536. [CrossRef] [PubMed]

20. von Bargen, S.; Al Kubrusli, R.; Gaskin, T.; Fürl, S.; Hüttner, F.; Blystad, D.R.; Karlin, D.G.; Jalkanen, R.; Büttner, C. Characterisation of a novel Emaravirus identified in mosaic-diseased Eurasian aspen (Populus tremula). Ann. Appl. Biol. 2020, 176, $210-222$. [CrossRef]

21. Kumar, S.; Subbarao, B.; Hallan, V. Molecular characterization of emaraviruses associated with Pigeonpea sterility mosaic disease. Sci. Rep. 2017, 7, 1-20. [CrossRef] [PubMed]

22. Elbeaino, T.; Digiaro, M.; Alabdullah, A.; De Stradis, A.; Minafra, A.; Mielke, N.; Castellano, M.A.; Martelli, G.P. A multipartite single-stranded negative-sense RNA virus is the putative agent of fig mosaic disease. J. Gen. Virol. 2009, 90, 1281-1288. [CrossRef] [PubMed]

23. Hassan, M.; Di Bello, P.L.; Keller, K.E.; Martin, R.R.; Sabanadzovic, S.; Tzanetakis, I.E. A new, widespread emaravirus discovered in blackberry. Virus Res. 2017, 235, 1-5. [CrossRef]

24. Walia, J.J.; Salem, N.M.; Falk, B.W. Partial sequence and survey analysis identify a multipartite, negative-sense RNA virus associated with fig mosaic. Plant Dis. 2009, 93, 4-10. [CrossRef]

25. Zheng, Y.; Navarro, B.; Wang, G.; Wang, Y.; Yang, Z.; Xu, W.; Zhu, C.; Wang, L.; Di Serio, F.; Hong, N. Actinidia chlorotic ringspot-associated virus: A novel emaravirus infecting kiwifruit plants. Mol. Plant Pathol. 2017, 18, 569-581. [CrossRef]

26. Buzkan, N.; Chiumenti, M.; Massart, S.; Sarpkaya, K.; Karadağ, S.; Minafra, A. A new emaravirus discovered in Pistacia from Turkey. Virus Res. 2019, 263, 159-163. [CrossRef]

27. Tatineni, S.; McMechan, A.J.; Wosula, E.N.; Wegulo, S.N.; Graybosch, R.A.; French, R.; Hein, G.L. An Eriophyid Mite-Transmitted Plant Virus Contains Eight Genomic RNA Segments with Unusual Heterogeneity in the Nucleocapsid Protein. J. Virol. 2014, 88, 11834-11845. [CrossRef] [PubMed]

28. Wang, Y.; Song, Y.; Cao, M.; Cheng, Q.; Wu, J.; Hu, T. Identification of a novel emaravirus infecting lilac through next-generation sequencing. J. Integr. Agric. 2020, 19, 2064-2071. [CrossRef]

29. Buck, K.W.; Kempson-Jones, F. Biophysical Properties of Penicillium stoloniferum Virus S. J. Virol. 1973, 18, 223-235. [CrossRef]

30. Vainio, E.J.; Chiba, S.; Ghabrial, S.A.; Maiss, E.; Roossinck, M.; Sabanadzovic, S.; Suzuki, N.; Xie, J.; Nibert, M.; Simmonds, P.; et al. ICTV Virus Taxonomy Profile: Partitiviridae. J. Gen. Virol. 2018, 99, 17-18. [CrossRef]

31. Nibert, M.L.; Ghabrial, S.A.; Maiss, E.; Lesker, T.; Vainio, E.J.; Jiang, D.; Suzuki, N. Taxonomic reorganization of family Partitiviridae and other recent progress in partitivirus research. Virus Res. 2014, 188, 128-141. [CrossRef] [PubMed]

32. Nibert, M.L.; Woods, K.M.; Upton, S.J.; Ghabrial, S.A. Cryspovirus: A new genus of protozoan viruses in the family Partitiviridae. Arch. Virol. 2009, 154, 1959-1965. [CrossRef]

33. Xin, M.; Cao, M.; Liu, W.; Ren, Y.; Lu, C.; Wang, X. The genomic and biological characterization of Citrullus lanatus cryptic virus infecting watermelon in China. Virus Res. 2017, 232, 106-112. [CrossRef]

34. Sela, N.; Lachman, O.; Reingold, V.; Dombrovsky, A. A new cryptic virus belonging to the family Partitiviridae was found in watermelon co-infected with Melon necrotic spot virus. Virus Genes 2013, 47, 382-384. [CrossRef] [PubMed]

35. Crawford, L.J.; Osman, T.A.M.; Booy, F.P.; Coutts, R.H.A.; Brasier, C.M.; Buck, K.W. Molecular characterization of a partitivirus from Ophiostoma himal-ulmi. Virus Genes 2006, 33, 33-39. [CrossRef]

36. Kim, H.; Park, D.; Hahn, Y. Identification of novel RNA viruses in alfalfa (Medicago sativa): An Alphapartitivirus, a Deltapartitivirus, and a Marafivirus. Gene 2018, 638, 7-12. [CrossRef]

37. Abe, J.; Nabeshima, T. First report of grapevine Pinot gris virus in wild grapevines (Vitis coignetiae) in Japan. J. Plant Pathol. 2021, in press. [CrossRef]

38. Giampetruzzi, A.; Roumi, V.; Roberto, R.; Malossini, U.; Yoshikawa, N.; La Notte, P.; Terlizzi, F.; Credi, R.; Saldarelli, P. A new grapevine virus discovered by deep sequencing of virus- and viroid-derived small RNAs in Cv Pinot gris. Virus Res. 2012, 163, 262-268. [CrossRef] 
39. Yoshikawa, N.; Iida, H.; Goto, S.; Magome, H.; Takahashi, T.; Terai, Y. Grapevine berry inner necrosis, a new trichovirus: Comparative studies with several known trichoviruses. Arch. Virol. 1997, 142, 1351-1363. [CrossRef]

40. Adams, M.J.; Antoniw, J.F.; Bar-Joseph, M.; Brunt, A.A.; Candresse, T.; Foster, G.D.; Martelli, G.P.; Milne, R.G.; Fauquet, C.M. The new plant virus family Flexiviridae and assessment of molecular criteria for species demarcation. Arch. Virol. 2004, 149, 1045-1060. [CrossRef] [PubMed] 